\title{
ESI-MS Study of Ionization Pathways and Cation-Receptor Properties of the Iron(II) Mono- and Bis-Clathrochelates
}

\author{
Oleg A. Varzatskii, ${ }^{a}$ Sergey V. Shul'ga, ${ }^{a}$ Henryk Kozlowski, ${ }^{\text {b }}$ Elzbieta Gumienna- \\ Kontecka, ${ }^{\text {b }}$ Lukasz Szyrwiel, ${ }^{\text {b }}$ Ekaterina G. Lebed, ${ }^{\mathrm{c}}$ and Yan Z. Voloshin ${ }^{\mathrm{Q}}$
}

Dedicated to the Corresponding member of the Russian Academy of Sciences Prof. Oscar Koifman on the occasion of his $70^{\text {th }}$ Birthday

\footnotetext{
${ }^{a}$ Vernadskii Institute of General and Inorganic Chemistry NASU, 03680 Kiev, Ukraine

${ }^{\mathrm{b}}$ Faculty of Chemistry, University of Wroclaw, 50-383 Wroclaw, Poland

${ }^{ }$Nesmeyanov Institute of Organoelement Compounds RAS, 119991 Moscow, Russia

${ }^{\circledR}$ Corresponding authorE-mail:voloshin@ineos.ac.ru
}

\begin{abstract}
Ionization pathways of iron(II) di- and hexachloromonoclathrochelates, bis-clathrochelates and their oximehydrazonate, dimethyl-and diamine-containing macrobicyclic analogs, and the cation-receptor properties of such cage compounds towards alkali metal cations (as individual ions or their mixtures) as well as the competitive complexation in the presence of 18-crown-6 were studied by ESI-MS method. Ionization of iron(II) mono- and bis-clathrochelates under the conditions of ESI-MS experiments was found to proceed via different pathways. The macrobicyclic iron(II) oximehydrazonate as an ionic associate of the clathrochelate cation with $\mathrm{BF}_{4}^{-}$anion undergoes the ionization by its heterolytic dissociation. The main pathways of ionization of the dioximate cage and bis-cage intracomplexes are substantially affected by ribbed substituents in their chelate fragments. The methyland amine-containing macrobicyclic complexes easily form anion-radical species by one-electron oxidation of their polyazomethine cage frameworks, whereas in the case of iron(II) dihalogenoclathrochelates the most intensive peaks correspond to their ionic associates with monocharged alkali metal cations. ESI-MS positive-mode spectrum of the iron(II) hexachloroclathrochelate contains no detectable peaks of the cationic species, which resulted either from its oxidation to the corresponding cation-radical or from its ionic associates with alkali metal cations. In the negative mode, an intensive peak assigned to the anion-radical product of one-electron reduction was observed. As ESI mass spectrometry allows maintaining precise concentrations of the complex under study and that of "cationization agents" (i.e., the compounds that promote formation of cationic species of the analyte and have been used in the case of low-ionizable complexes), the alkali metal tetraphenylborates were applied as such agents to study cation-receptor properties of the iron(II) mono- and bis-clathrochelates with ribbed substituents of the different nature towards these metal ions. Iron(II) monoclathrochelates form two types of ionic associates with such cations with both the 1:1 and 2:1 stoichiometries, which are more and less intensive in their ESI-MSs, respectively, whereas ESI-MSs of bis-cage complexes contain the intensive peaks of only 1:1 ionic associates with high affinity towards $\mathrm{Cs}^{+}$cation.
\end{abstract}

Keywords: Macrocyclic compounds, clathrochelates, iron complexes, ionic mass spectrometry, receptors. 


\title{
Исследование путей ионизации и катион-рецепторных свойств моно- и бис-клатрохелатов железа(II) методом ESI масс- спектрометрии
}

\author{
О. А. Варзацкий, ${ }^{a}$ C. В. Шульга, ${ }^{a}$ Х. Козловски, ${ }^{\text {b }}$ Э. Гуменна-Контека, ${ }^{b}$ \\ ^. Жирвел, ${ }^{\text {b }}$ Е. Г. Лебедь, ${ }^{\text {c }}$ Я. З. Волошин ${ }^{\text {@ }}$ \\ Посвящается член-корреспонденту РАН, профессору Оскару Иосифовичу Койфману \\ по случаю его 70-летнего юбилея
}

\begin{abstract}
${ }^{\mathrm{a}}$ Институт общей и неорганической химии им. Вернадского НАН Украинь, 03680 Киев, Украина
${ }^{\mathrm{b}}$ Химический факультет, Вроилавский университет, 50-383 Врочлав, Польша

' Институт элементоорганических соединений им. А.Н. Несмеянова РАН, 119991 Москва, Россия

@E-mail:voloshin@ineos.ac.ru
\end{abstract}

\begin{abstract}
Методом ESI масс-спектрометрии были изучены пути ионизации ди- и гексахлоромоноклатрохелатов железа(II), бис-клатрохелатов железа(II) и их оксимгидразонатных макробициклических аналогов, а также катион-рецепторные свойства этих комплексов по отношению к катионам щелочных металлов.
\end{abstract}

Ключевыеслова: макроциклические соединения, клатрохелаты, комплексы железа, ионная масс-спектрометрия, рецепторы.

\section{Introduction}

Macrobicyclic $d$-metal tris-dioximates and trisoximehydrazonates belong to a unique type of cage complexes (the so-called clathrochelates), with a caged transition metal ion fully encapsulated in a three-dimentional cavity of a rigid polyene macrobicyclic ligand isolating it from external factors. ${ }^{[1]}$ Biological activity of such compounds as enzymatic regulators in the systems of biosynthesis of nucleic acids has recently started to attract much attention. $[2,3]$ The interest of biochemists and molecular biologists in $d$-metal clathrochelates has been triggered by their high synthetic availability, (photo)chemical stability, and the activity of a series of iron(II) clathrochelates as efficient transcription inhibitors for the T7 RNA polymerase. ${ }^{[3]}$ We have recently succeeded to boost the inhibitory activity of cage compounds by direct joining of two macrobicyclic fragments with a covalent bond, ${ }^{[4]}$ while keeping all the advantages of clathrochelates as enzyme inhibitors in submicromolar range. Such iron(II) bis-clathrochelates have an incredible chemical stability and low toxicity, are easy to synthesize from available and inexpensive initial compounds, and have favorable geometry allowing introduction of up to fourteen substituents. These cage complexes have been also used as versatile guests to form strong supramolecular assemblies with blood transport proteins - serum albumins, but discriminating other globular proteins, ${ }^{[5]}$ and have been shown to affect protein uncontrolled aggregation by changing the kinetics of insulin fibrillization and reducing the amount of amyloid fibrils formed and suppressing the formation of superfibrillar species as well. ${ }^{[6]}$ This demonstrates huge potential of cage metal complexes as prospective antiviral and anticancer drug candidates (the so-called "topological drugs"[2-6]). The cage complexes have been also proposed ${ }^{[7-28]}$ as molecular scaffolds for the design of multicentred molecular and supramolecular systems for the target delivery of an encapsulated radionuclide as well as (radio)diagnostic and (radio)therapeutic compounds (in particular, for ${ }^{11} \mathrm{~B}-\mathrm{NCT}$ treatment ${ }^{[24-28]}$ ).

The $\alpha$-dioximate fragments of some mono- and triribbed-functionalized metal clathrochelates contain in such chelate moieties the donor vic-substituents (halogen atoms, amine, hydroxyl and mercapto groups) that are able to coordinate to a metal ion. ${ }^{[29-31]}$ We thus aimed on studying cation-receptor properties of halogen-containing iron(II) mono- and bis-clathrochelates (Scheme 1) having from two $\left(\mathrm{FeBd}_{2}\left(\mathrm{Cl}_{2} \mathrm{Gm}\right)(\mathrm{BF})_{2}, \quad \mathrm{FeBd}_{2}\left(\mathrm{Br}_{2} \mathrm{Gm}\right)(\mathrm{BF})_{2}, \quad \mathrm{FeBd}_{2}\left(\mathrm{I}_{2} \mathrm{Gm}\right)\right.$ $(\mathrm{BF})_{2},\left\{\mathrm{FeBd}_{2}(\mathrm{BrGm})(\mathrm{BF})_{2}\right\}_{2}$ and $\left.\left\{\mathrm{FeBd}_{2}(\mathrm{IGm})(\mathrm{BF})_{2}\right\}_{2}\right)$ to six $\left(\mathrm{Fe}\left(\mathrm{Cl}_{2} \mathrm{Gm}\right)_{3}\left(\mathrm{~B} n-\mathrm{C}_{4} \mathrm{H}_{9}\right)_{2}\right)$ chlorine atoms in their chelate $\alpha$-dioximate fragments. Note that these reactive compounds have been earlier recognized as convenient macrobicyclic precursors for their further functionalization with $N, O, C, S$ nucleophiles ${ }^{[3,24,27,29-38]}$ (including those with ionophoric, pharmacophoric and fluorophoric groups), and for the design of hybride and multicentered compounds. ${ }^{[2,27,28]}$ Here we also describe the cation-receptor properties of their dimethyl- and diamine-containing clathrochelate analogs $\mathrm{FeBd}_{2} \mathrm{Dm}(\mathrm{BF})_{2}$ and $\mathrm{FeBd}_{2}\left(\left(\left(\mathrm{CH}_{3}\right)_{2} \mathrm{~N}\right)\left(\mathrm{NH}_{2}\right) \mathrm{Gm}\right)(\mathrm{BF})_{2}$ towards alkali metal cations (as individual species or their mixtures), together with the peculiarities of ESI-MS ionization of such cage compounds; the clathrochelate oximehydrazonate $\left[\mathrm{FeDXO}_{3}\left(\mathrm{HCOC}_{2} \mathrm{H}_{5}\right)_{3}\left(\mathrm{BC}_{6} \mathrm{H}_{5}\right)\right]\left(\mathrm{BF}_{4}\right)$, containing a macrobicyclic cation with $m / z 654.27 \mathrm{Da}$, was used as an internal standard. We have also studied a competitive complexation of these clathrochelates with alkali metal cations in the presence of 18-crown-6 forming stable complexes with them. 


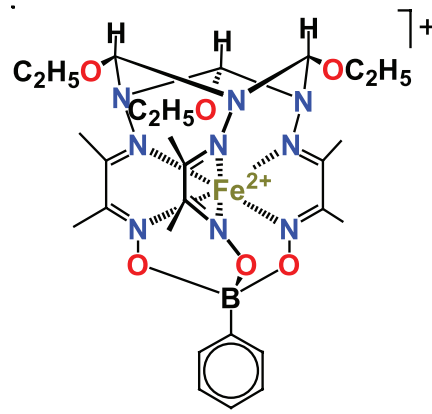

$\left[\mathrm{FeDXO}{ }_{3}\left(\mathrm{HCOC}_{2} \mathrm{H}_{5}\right)_{3}\left(\mathrm{BC}_{6} \mathrm{H}_{5}\right)\right]\left(\mathrm{BF}_{4}\right)$

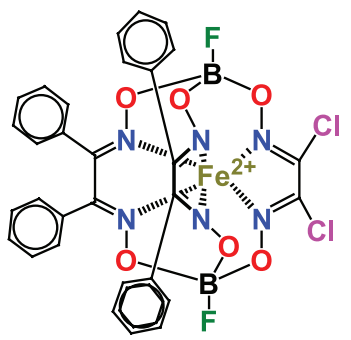

$\mathrm{FeBd}_{2}\left(\mathrm{Cl}_{2} \mathrm{Gm}\right)(\mathrm{BF})_{2}$

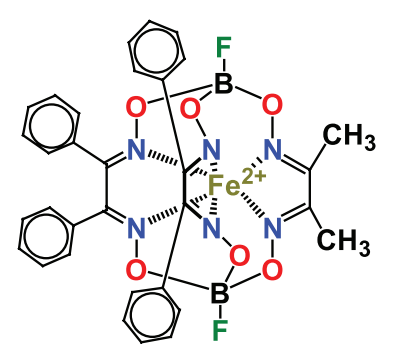

$\mathrm{FeBd}_{2} \mathrm{Dm}(\mathrm{BF})_{2}$

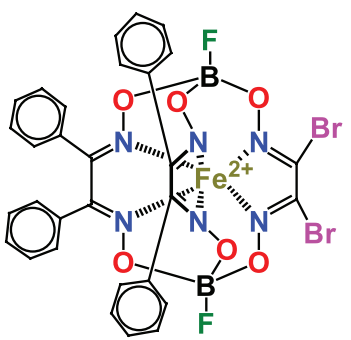

$\mathrm{FeBd}_{2}\left(\mathrm{Br}_{2} \mathrm{Gm}\right)(\mathrm{BF})_{2}$

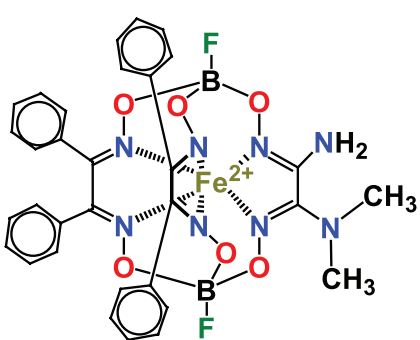

$\mathrm{FeBd}_{2}\left(\left(\left(\mathrm{CH}_{3}\right)_{2} \mathrm{~N}\right)\left(\mathrm{NH}_{2}\right) \mathrm{Gm}\right)(\mathrm{BF})_{2}$

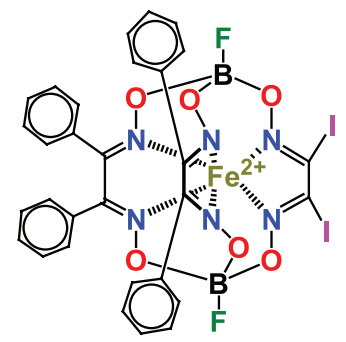

$\mathrm{FeBd}_{2}\left(\mathrm{I}_{2} \mathrm{Gm}\right)(\mathrm{BF})_{2}$

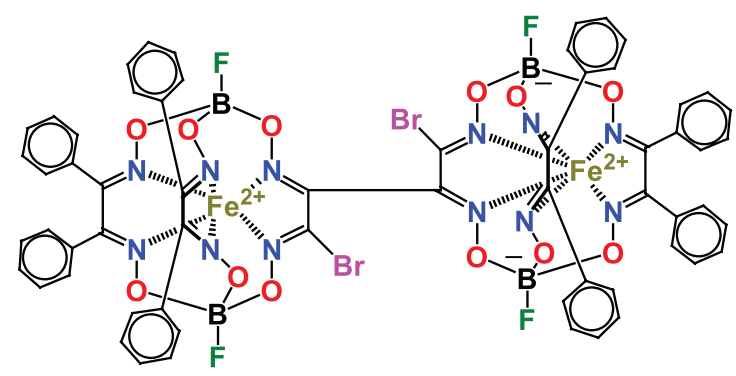

$\left\{\mathrm{FeBd}_{2}(\mathrm{BrGm})(\mathrm{BF})_{2}\right\}_{2}$

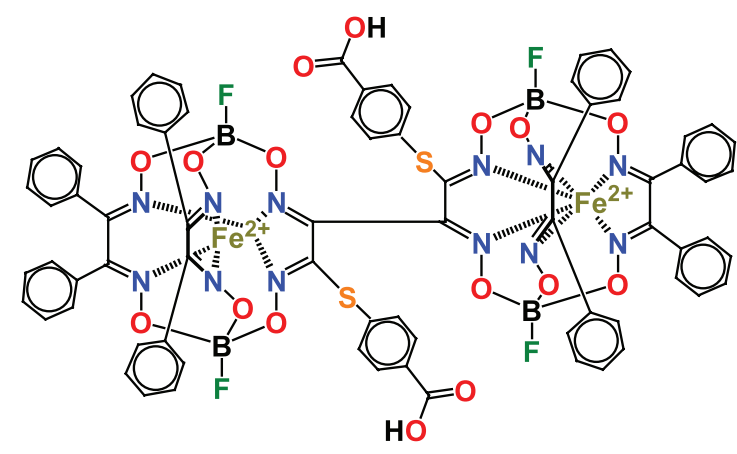

$\left\{\mathrm{FeBd}_{2}\left(\left(\mathrm{HOOCC}_{6} \mathrm{H}_{4} \mathrm{~S}\right) \mathrm{Gm}\right)(\mathrm{BF})_{2}\right\}_{2}$

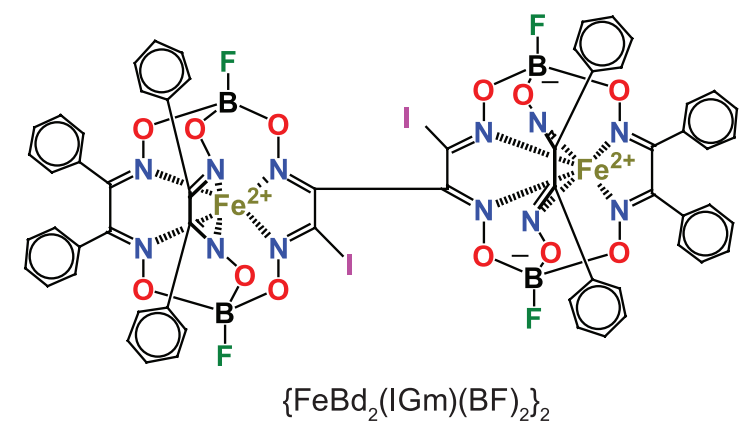

(1)

$\mathrm{Fe}\left(\mathrm{Cl}_{2} \mathrm{Gm}\right)_{3}\left(\mathrm{Bn}-\mathrm{C}_{4} \mathrm{H}_{9}\right)_{2}$

Scheme 1.

\section{Experimental}

Sodium, potassium, cesium and rubidium tetraphenylborates as well as organic solvents (analytical grade) were obtained commercially (SAF). The iron(II) mono- and bis-clathrochelates under study were obtained as described previously. ${ }^{[4,32,37-42]}$

ESI-MS were obtained on a Bruker MicrOTOF-Q spectrometer equipped with an Apollo II electrospray ionization source with an ion funnel. The instrumental parameters were as follows: scan range $m / z$ 200-2200 Da, dry gas: nitrogen, temperature $200{ }^{\circ} \mathrm{C}$, transfer time $120 \mathrm{ps}$. The sample was infused at a flow rate of $3 \mu \mathrm{L} \cdot \mathrm{min}^{-1}$. Before each run, the spectrometer was calibrated externally with the Tunemix ${ }^{\mathrm{TM}}$ mixture (Bruker Daltonik, Germany) in a quadratic regression mode. The mass accuracy for the calibration was better than $5 \mathrm{ppm}$, together with the true isotopic pattern (using a SigmaFit) enabling an unambiguous conformation of the elemental composition of the clathrochelate complexes studied. 
Table 1. ESI-MS data for the iron(II) dihalogenoclathrochelates in the presence of equimolar amounts of alkali metal cations.

\begin{tabular}{|c|c|c|c|c|c|c|c|c|c|c|c|c|}
\hline \multirow{3}{*}{$\begin{array}{l} \\
\mathrm{FeBd}_{2}\left(\mathrm{Cl}_{2} \mathrm{Gm}\right)(\mathrm{BF})_{2} \\
\text { Intensity (a.u.) }\end{array}$} & \multicolumn{3}{|c|}{ System $\mathrm{M}+\mathrm{Na}^{+}$} & \multicolumn{3}{|c|}{ System $\mathrm{M}+\mathrm{K}^{+}$} & \multicolumn{3}{|c|}{ System $\mathrm{M}+\mathrm{Rb}^{+}$} & \multicolumn{3}{|c|}{ System $\mathrm{M}+\mathrm{Cs}^{+}$} \\
\hline & {$[\mathrm{M}]^{+}$} & {$\left[\mathrm{M}+\mathrm{Na}^{+}\right]^{+}$} & {$\left[2 \mathrm{M}+\mathrm{Na}^{+}\right]^{+}$} & {$[\mathrm{M}]^{+} \cdot$} & {$\left[\mathrm{M}+\mathrm{K}^{+}\right]^{+}$} & {$\left[2 \mathrm{M}+\mathrm{K}^{+}\right]^{+}$} & {$[\mathrm{M}]^{+}$} & {$\left[\mathrm{M}+\mathrm{Rb}^{+}\right]^{+}$} & {$\left[2 \mathrm{M}+\mathrm{Rb}^{+}\right]^{+}$} & {$[\mathrm{M}]^{+}$} & {$\left[\mathrm{M}+\mathrm{Cs}^{+}\right]^{+}$} & {$\left[2 \mathrm{M}+\mathrm{Cs}^{+}\right]^{+}$} \\
\hline & 125 & 42065 & 5590 & 929 & 9220 & 1727 & 4639 & 5777 & 663 & 2033 & 35115 & 1637 \\
\hline$I$ rel. (\%) & 0.3 & 100 & 11.7 & 10.08 & 100 & 18.73 & 80.31 & 100 & 11.48 & 5.79 & 100 & 4.66 \\
\hline I/Isum. (\%) & 0.26 & 88.04 & 11.70 & 7.82 & 77.64 & 14.54 & 41.87 & 52.14 & 5.98 & 5.24 & 90.54 & 4.22 \\
\hline$m / z(\mathrm{Da})$ & 747.04 & 769.02 & 785 & 747.04 & 785.00 & 1533.08 & 747.04 & 830.95 & 1577.99 & 747.04 & 878.93 & 1625.96 \\
\hline $\begin{array}{l}\mathrm{FeBd}_{2}\left(\mathrm{Br}_{2} \mathrm{Gm}\right)(\mathrm{BF})_{2} \\
\text { Intensity (a.u.) }\end{array}$ & 223 & 10741 & 1781 & 579 & 7993 & 1044 & 1482 & 6817 & 895 & 564 & 16652 & 1595 \\
\hline$I$ rel. (\%) & 2.07 & 100 & 16.58 & 7.24 & 100 & 13.06 & 21.74 & 100 & 13.13 & 3.39 & 100 & 9.58 \\
\hline I/Isum. (\%) & 1.75 & 84.28 & 13.97 & 6.02 & 83.12 & 10.86 & 16.12 & 74.15 & 9.73 & 3.00 & 88.52 & 8.48 \\
\hline$m / z(\mathrm{Da})$ & 835.95 & 858.92 & 1693.87 & 835.95 & 874.89 & 1710.85 & 835.95 & 920.85 & 1756.77 & 835.95 & 968.85 & 1804.80 \\
\hline $\begin{array}{l}\mathrm{FeBd}_{2}\left(\mathrm{I}_{2} \mathrm{Gm}\right)(\mathrm{BF})_{2} \\
\text { Intensity (a.u.) }\end{array}$ & 144 & 3339 & 323 & 181 & 2080 & 256 & 80 & 3215 & 352 & 159 & 13277 & 1242 \\
\hline I rel. (\%) & 4.31 & 100 & 9.68 & 8.71 & 100 & 12.3 & 2.49 & 100 & 10.94 & 1.2 & 100 & 9.36 \\
\hline I/Isum. (\%) & 3.78 & 87.73 & 8.49 & 7.19 & 82.64 & 10.17 & 2.19 & 88.15 & 9.65 & 1.08 & 90.46 & 8.46 \\
\hline$m / z(\mathrm{Da})$ & 931.29 & 952.89 & 1882.82 & 931.29 & 968.87 & 1898.81 & 931.29 & 1014.82 & 1944.72 & 931.29 & 1062.82 & 1992.76 \\
\hline
\end{tabular}

Table 2. ESI-MS data for the iron(II) bis-clathrochelates in the presence of equimolar amounts of alkali metal cations.

\begin{tabular}{|c|c|c|c|c|c|}
\hline & {$[\mathrm{M}]^{+} \cdot$} & {$\left[\mathrm{M}+\mathrm{Na}^{+}\right]^{+}$} & {$\left[\mathrm{M}+\mathrm{K}^{+}\right]^{+}$} & {$\left[\mathrm{M}+\mathrm{Rb}^{+}\right]^{+}$} & {$\left[\mathrm{M}+\mathrm{Cs}^{+}\right]^{+}$} \\
\hline $\multicolumn{6}{|c|}{\mathrm{FeBd}_{2}(\mathrm{IGm})(\mathrm{BF})_{2}}_{2}$ \\
\hline Intensity (a.u.) & 5421826 & 44465056 & 14798896 & 4853671 & 194648607 \\
\hline a I rel. (\%) & 3 & 23 & 8 & 2 & 100 \\
\hline bI/Isum. (\%) & 2 & 17 & 6 & 2 & 74 \\
\hline$m / z(\mathrm{Da})$ & 1354 & 1377 & 1393 & 1439 & 1487 \\
\hline $\multicolumn{6}{|c|}{\mathrm{FeBd}_{2}(\mathrm{BrGm})(\mathrm{BF})_{2}}_{2}$ \\
\hline Intensity (a.u.) & 9650692 & 21359035 & 34330723 & 69080510 & 159036327 \\
\hline a $I$ rel. $(\%)$ & 6 & 13 & 22 & 43 & 100 \\
\hline b $I / I$ sum. (\%) & 3 & 7 & 12 & 24 & 54 \\
\hline$m / z(\mathrm{Da})$ & 1512.1 & 1535.1 & 1551.1 & 1597.0 & 1645.0 \\
\hline $\multicolumn{6}{|c|}{\mathrm{FeBd}_{2}\left(\left(\mathrm{HOOCC}{ }_{6} \mathrm{H}_{4} \mathrm{~S}\right) \mathrm{Gm}\right)(\mathrm{BF})_{2}}_{2}$ \\
\hline Intensity (a.u.) & 3048045 & 1158679 & 10354901 & 2711655 & 25094479 \\
\hline${ }^{\mathrm{a}} I \mathrm{rel} .(\%)$ & 12 & 5 & 41 & 11 & 100 \\
\hline bI/Isum. (\%) & 7 & 3 & 24 & 6 & 59 \\
\hline$m / z(\mathrm{Da})$ & 1658.3 & 1681.3 & 1697.2 & 1744.3 & 1791.2 \\
\hline
\end{tabular}

antensity relative to most intensive peak;

${ }^{\mathrm{b}}$ Relative intensity to the sum of all peaks observed.

$1 \mathrm{mM}$ solutions of the complexes studied and alkali metal tetraphenylborates were obtained by a dissolution of their weighted amounts in pure acetonitrile for $20 \mathrm{~min}$ with an ultrasonic dispergation followed by a centrifugation.

Four series of the ESI-MS experiments were performed (a-d, below). (a) The mass spectra of the acetonitrile solutions of these complexes were obtained at their concentrations $5 \cdot 10^{-5} \mathrm{~mol} \cdot \mathrm{l}^{-1}$. (b) The spectral data were collected for the mixtures of $1 \mathrm{mM}$ acetonitrile solution of the cage complex under study $(25 \mu \mathrm{l})$, $1 \mathrm{mM}$ acetonitrile solution of the corresponding alkali metal tetraphenylborate $(25 \mu \mathrm{l})$ and acetonitrile $(450 \mu \mathrm{l})$. The obtained solutions with equimolar concentrations of the components equal to $5 \cdot 10^{-5} \mathrm{~mol} \cdot \mathrm{l}^{-1}$ underwent an ultrasonic dispergation and then were studied at the same experimental conditions; the corresponding ESI-MS data are summarized in Tables 1 and 2. (c) The ESI-MSs from the mixtures of $1 \mathrm{mM}$ acetonitrile solution of the clathrochelate under study $(25 \mu \mathrm{l})$ and $1 \mathrm{mM}$ acetonitrile solutions of the sodium, potassium, rubidium and cesium tetraphenylborates (25 $\mu$ l each) and acetonitrile $(375 \mu l)$ were recorded. The solutions obtained with equimolar concentrations of the components equal to $5 \cdot 10^{-5} \mathrm{~mol} \cdot \mathrm{l}^{-1}$ were treated and studied as described above; the corresponding ESI-MS data are summarized in Table 3. (d) Finally, the concurrent complexation of the mono- and bisclathrochelates $\mathrm{FeBd}_{2}\left(\mathrm{Br}_{2} \mathrm{Gm}\right)(\mathrm{BF})_{2},\left\{\mathrm{FeBd}_{2}\left(\mathrm{Gm}-\mathrm{S}-\mathrm{C}_{6} \mathrm{H}_{4}-\mathrm{COOH}\right)\right.$ $\left.(\mathrm{BF})_{2}\right\}_{2}$ and $\left\{\mathrm{FeBd}_{2}(\mathrm{BrGm})(\mathrm{BF})_{2}\right\}_{2}$ with alkali metal cations in the presence of 18-crown- 6 was studied. Two microsyringes (one containing $50 \mu \mathrm{M}$ acetonitrile solution of 18 -crown- 6 , the other a mixture of acetonitrile solutions of the clathrochelate under study, 
ESI-MS Study of Iron(II) Mono- and Bis-Clathrochelates

Table 3. ESI-MS data for the iron(II) clathrochelates in the presence of equimolar mixture of alkali metal cations.

\begin{tabular}{|c|c|c|c|c|c|c|c|c|c|}
\hline Compound & {$[\mathrm{M}]^{+\cdot}$} & {$\left[\mathrm{M}+\mathrm{Na}^{+}\right]^{+}$} & {$\left[\mathrm{M}+\mathrm{K}^{+}\right]^{+}$} & {$\left[\mathrm{M}+\mathrm{Rb}^{+}\right]^{+}$} & {$\left[\mathrm{M}+\mathrm{Cs}^{+}\right]^{+}$} & {$\left[2 \mathrm{M}+\mathrm{Na}^{+}\right]^{+}$} & {$\left[2 \mathrm{M}+\mathrm{K}^{+}\right]^{+}$} & {$\left[2 \mathrm{M}+\mathrm{Rb}^{+}\right]^{+}$} & {$\left[2 \mathrm{M}+\mathrm{Cs}^{+}\right]^{+}$} \\
\hline $\begin{array}{l}\mathrm{FeBd}_{2}\left(\mathrm{Cl}_{2} \mathrm{Gm}\right)(\mathrm{BF})_{2} \\
\text { Intensity (a.u.) }\end{array}$ & 1787 & 36652 & 12236 & 14088 & 44738 & 6508 & 1414 & 1302 & 1944 \\
\hline I rel. (\%) & 4 & 82 & 27 & 31 & 100 & 15 & 3 & 3 & 4 \\
\hline I/Isum. (\%) & 1.5 & 30.4 & 10.1 & 11.7 & 37.1 & 5.4 & 1.2 & 1.1 & 1.6 \\
\hline$m / z(\mathrm{Da})$ & 746 & 769 & 785 & 832.9 & 878 & 1517.1 & 1533 & 1579 & 1627 \\
\hline $\begin{array}{l}\mathrm{FeBd}_{2}\left(\mathrm{Br}_{2} \mathrm{Gm}\right)(\mathrm{BF})_{2} \\
\text { Intensity (a.u.) }\end{array}$ & 669 & 17058 & 7777 & 10721 & 29096 & 1872 & 954 & 909 & 1667 \\
\hline I rel. (\%) & 2.3 & 58.64 & 26.73 & 36.85 & 100 & 6.43 & 3.28 & 3.12 & 5.74 \\
\hline I/Isum. (\%) & 0.9 & 24.1 & 11.0 & 15.2 & 41.1 & 2.6 & 1.3 & 1.3 & 2.4 \\
\hline$m / z(\mathrm{Da})$ & 836 & 859 & 875 & 921 & 969 & 1695 & 1711 & 1757 & 11805 \\
\hline $\begin{array}{l}\mathrm{FeBd}_{2}\left(\mathrm{I}_{2} \mathrm{Gm}\right)(\mathrm{BF})_{2} \\
\text { Intensity (a.u.) }\end{array}$ & 5088 & 11616 & 17176 & 16601 & 33890 & 1207 & 2495 & 2721 & 4476 \\
\hline I rel. (\%) & 15 & 34 & 51 & 49 & 100 & 4 & 7 & 8 & 13 \\
\hline I/Isum. (\%) & 5.3 & 12.2 & 18.0 & 17.4 & 35.6 & 1.3 & 2.6 & 2.9 & 4.7 \\
\hline$m / z(\mathrm{Da})$ & 930 & 953 & 969 & 1015 & 1063 & 1883 & 1899 & 1945 & 1993 \\
\hline $\begin{array}{c}\mathrm{FeBd}_{2}\left(\left(\mathrm{CH}_{3}\right)_{2} \mathrm{~N}\right) \\
\left.\left(\mathrm{NH}_{2}\right) \mathrm{Gm}\right)(\mathrm{BF})_{2} \\
\text { Intensity (a.u.) }\end{array}$ & 23488991 & 26358082 & 10313148 & 5359212 & 65273469 & 17746021 & 7985475 & 2940943 & 14866928 \\
\hline I rel. (\%) & 35.99 & 40.38 & 15.80 & 8.21 & 100 & 27.19 & 12.23 & 4.51 & 22.78 \\
\hline I/Isum. (\%) & 13.47 & 15.12 & 5.92 & 3.07 & 37.44 & 10.18 & 4.58 & 1.69 & 8.53 \\
\hline$m / z(\mathrm{Da})$ & 736 & 759 & 775 & 821 & 869 & 1495 & 1511 & 1557 & 1605 \\
\hline
\end{tabular}

Table 4. ESI-MS data for the dibromine-containing iron(II) mono- and bis-clathrochelates and their equimolar mixture in the presence of equimolar amounts of the pair of cations $\mathrm{Na}^{+} / \mathrm{Cs}^{+}$and the clathrochelate oximehydrazonate cation $\left[\mathrm{FeDXO}_{3}\left(\mathrm{HCOC}_{2} \mathrm{H}_{5}\right)_{3}\left(\mathrm{BC}_{6} \mathrm{H}_{5}\right)\right]\left(\mathrm{BF}_{4}\right)$ as an internal standart.

\begin{tabular}{|c|c|c|c|c|c|c|}
\hline & $\begin{array}{c}{\left[\mathrm{FeDXO}{ }_{3}\left(\mathrm{HCOC}_{2} \mathrm{H}_{5}\right)_{3}\right.} \\
\left.\left(\mathrm{BC}_{6} \mathrm{H}_{5}\right)\right]\left(\mathrm{BF}_{4}\right)\end{array}$ & {$\left[\mathrm{M}+\mathrm{Na}^{+}\right]^{+}$} & {$\left[\mathrm{M}+\mathrm{Cs}^{+}\right]^{+}$} & $\begin{array}{l}{\left[\mathrm{M}+\mathrm{Cs}^{+}+\right.} \\
\left.\mathrm{CH}_{3} \mathrm{OH}\right]^{+}\end{array}$ & {$\left[2 \mathrm{M}+\mathrm{Na}^{+}\right]^{+}$} & {$\left[2 \mathrm{M}+\mathrm{Cs}^{+}\right]^{+}$} \\
\hline \multicolumn{7}{|c|}{$\mathrm{FeBd}_{2}\left(\mathrm{Br}_{2} \mathrm{Gm}\right)(\mathrm{BF})_{2}$} \\
\hline Intensity (a.u.) & 310950295 & 40319282 & 426289171 & 329399064 & 6599297 & 42410201 \\
\hline I rel. $(\%)$ & 72.94 & 9.46 & 100.00 & 77.27 & 1.55 & 9.95 \\
\hline$m / z(\mathrm{Da})$ & 654.2763 & 858.9437 & 968.8625 & 1001.0472 & 1694.9327 & 1804.8293 \\
\hline $\multicolumn{7}{|c|}{\mathrm{FeBd}_{2}(\mathrm{BrGm})(\mathrm{BF})_{2}}_{2}$ \\
\hline Intensity (a.u.) & 134745266 & 20408569 & 224523368 & 75100143 & & \\
\hline I rel. (\%) & 60.01 & 9.09 & 100.00 & 33.45 & & \\
\hline$m / z(\mathrm{Da})$ & 654.2744 & 1535.0809 & 1645.0029 & 1677.1763 & & \\
\hline \multicolumn{7}{|c|}{$\begin{array}{l}\mathrm{FeBd}_{2} \mathrm{Br}_{2} \mathrm{Gm}(\mathrm{BF})_{2}+ \\
\left\{\mathrm{FeBd}_{2} \mathrm{BrGm}(\mathrm{BF})_{2}\right\}_{2}\end{array}$} \\
\hline Intensity (a.u.) & 85172319 & $\begin{array}{l}14138276 \\
12580616\end{array}$ & $\begin{array}{l}71549421 \\
96842853\end{array}$ & $\begin{array}{l}63493095 \\
28829004\end{array}$ & 1228349 & 8982712 \\
\hline I rel. (\%) & 87.95 & $\begin{array}{l}14.60 \\
12.99\end{array}$ & $\begin{array}{c}73.88 \\
100.00\end{array}$ & $\begin{array}{l}65.56 \\
29.77\end{array}$ & 1.27 & 9.28 \\
\hline$m / z(\mathrm{Da})$ & 654.2764 & $\begin{array}{c}858.9437 \\
1535.0803\end{array}$ & $\begin{array}{c}968.8624 \\
1645.0028\end{array}$ & $\begin{array}{l}1001.0472 \\
1677.1765\end{array}$ & 1694.9332 & 8982712 \\
\hline
\end{tabular}

cesium tetraphenylborate, and oximehydrazonate clathrochelate $\left[\mathrm{FeDXO}_{3}\left(\mathrm{HCOC}_{2} \mathrm{H}_{5}\right)_{3}\left(\mathrm{BC}_{6} \mathrm{H}_{5}\right)\right]\left(\mathrm{BF}_{4}\right)$ as an internal standard, at the same concentrations) were connected with input unit of the sample into a spectrometer by a mixer. The rates of the addition of these solutions to the mixer were controlled in such a manner that their volumes in the mixer were constant; the spectra were recorded at each step and the data obtained are summarized in Table 5.

\section{Results and Discussion}

In contrast to MALDI-TOF mass spectrometry, with the concentration of an analyte depending on the coordinates of the laser-irradiated point on a target, the ESI mass spectrometry allows maintaining precise concentrations of the complex under study and those of the "cationization 
Table 5. ESI-MS data for the mixtures of the clathrochelate $\mathrm{FeBd}_{2} \mathrm{Br}_{2} \mathrm{Gm}(\mathrm{BF})_{2}-\mathrm{Cs}^{+}$- 18-crown-6.

\begin{tabular}{|c|c|c|c|c|c|}
\hline $\begin{array}{c}\text { Clathrochelate-to-18-crown-6 } \\
\text { molar ratio }\end{array}$ & $\begin{array}{l}\text { without } 18- \\
\text { crown-6 }\end{array}$ & 1 & 2 & 6 & 8 \\
\hline \multicolumn{6}{|l|}{$\left[\mathrm{M}+\mathrm{Cs}^{+}\right]^{+}$} \\
\hline I rel. $(\%)$ & 20.12 & 23.01 & 6.01 & 0.14 & 0.08 \\
\hline$m / z(\mathrm{Da})$ & 968.8634 & 968.8636 & 968.8635 & 968.8595 & 968.8636 \\
\hline \multicolumn{6}{|l|}{$\left[\mathrm{M}+\mathrm{Cs}^{+}+\mathrm{CH}_{3} \mathrm{OH}\right]^{+}$} \\
\hline I rel. $(\%)$ & 32.97 & 31.74 & 13.86 & 5.82 & 2.15 \\
\hline$m / z(\mathrm{Da})$ & 1001.0485 & 1001.0485 & 1001.0484 & 1001.0484 & 1001.0485 \\
\hline \multicolumn{6}{|l|}{$\left[2 \mathrm{M}+\mathrm{Cs}^{+}\right]^{+}$} \\
\hline$I$ rel. $(\%)$ & 24.09 & 21.31 & 3.76 & 0.99 & 0.85 \\
\hline$m / z(\mathrm{Da})$ & 1804.8643 & 1804.8644 & 1804.8645 & 1804.8648 & 1804.8647 \\
\hline \multicolumn{6}{|l|}{$\left[18 \text {-crown- } 6+\mathrm{Cs}^{+}\right]^{+}$} \\
\hline I rel. $(\%)$ & 0.00 & 7.80 & 48.77 & 84.87 & 100.00 \\
\hline$m / z(\mathrm{Da})$ & 397.0653 & 397.0606 & 397.0653 & 397.0653 & 397.0653 \\
\hline
\end{tabular}

agents" (i.e., the compounds that promote formation of cationic species of an analyte and are used in the case of low-ionizable complexes).

We have used the alkali metal tetraphenylborates as the cationization agents to study cation-receptor properties of the iron(II) mono- and bis-clathrochelates with ribbed substituents of the different nature towards various alkali metal cations.

In the absence ofalkalimetal tetraphenylborates, the main pathway of the ionization of the alkyl- and amine-containing clathrochelates $\mathrm{FeBd}_{2} \mathrm{Dm}(\mathrm{BF})_{2}$ and $\mathrm{FeBd}_{2}\left(\left(\left(\mathrm{CH}_{3}\right)_{2} \mathrm{~N}\right)\left(\mathrm{NH}_{2}\right)\right.$ $\mathrm{Gm})(\mathrm{BF})_{2}$ under the ESI-MS experimental conditions is their one-electron oxidation resulting in the molecular ions $[\mathrm{M}]^{+}$. When the equimolar or excess amounts of these cationization agents are present, the corresponding spectra show intensive peaks of the ionic associates between the cage complexes and alkali metal cations (Table 1).

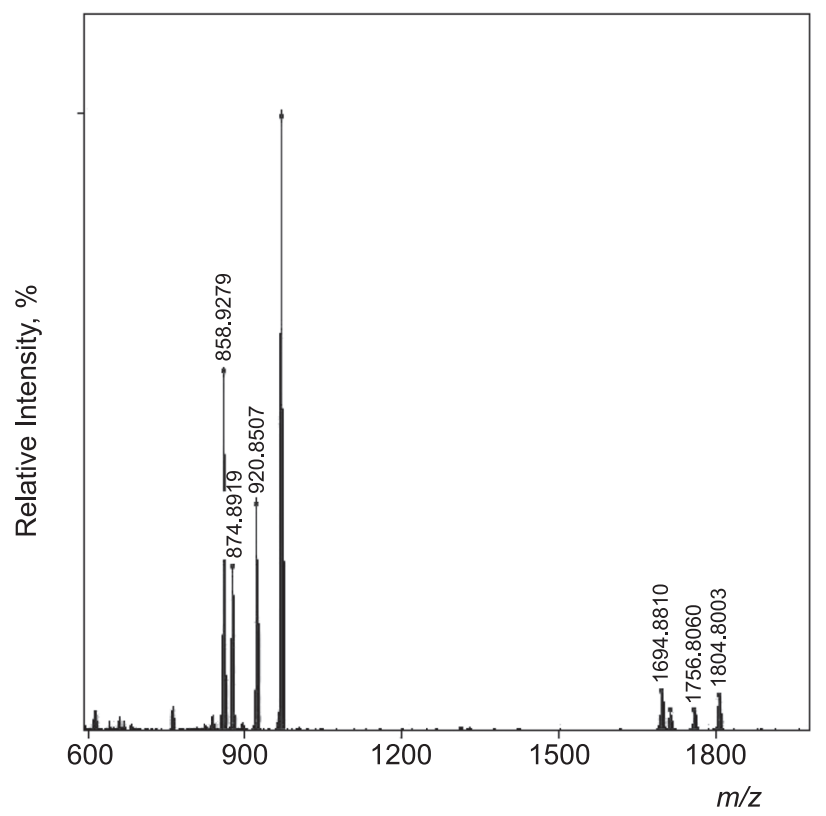

Figure 1. Positive range of ESI-MS for the clathrochelate $\mathrm{FeBd}_{2}\left(\mathrm{Br}_{2} \mathrm{Gm}\right)(\mathrm{BF})_{2}$ in the presence of equimolar amounts of sodium, potassium, rubidium and cesium tetraphenylborates.
The initial ESI-MSs of the iron(II) dihalogenoclathrohelates contain the low-intensive peaks of their ionic associates with impurity $\mathrm{Na}^{+}$and $\mathrm{K}^{+}$cations. In the presence of the alkali metal tetraphenylborates, the intensities of these peaks increase; ESI-MS of the acetonitrile solution of dibromoclathrochelate $\mathrm{FeBd}_{2}\left(\mathrm{Br}_{2} \mathrm{Gm}\right)(\mathrm{BF})_{2}$ with the equimolar amounts of sodium, potassium, rubidium and cesium tetraphenylborates is shown in Figure 1. This spectrum contains two groups of the most intensive peaks: (i) with $\mathrm{m} / \mathrm{z}$ from 858 to $969 \mathrm{Da}$, assigned to the monocharged ionic associates of this cage complex with alkali metal cations $\left[\mathrm{M}+\mathrm{Cat}^{+}\right]^{+}$, and (ii) with $\mathrm{m} / \mathrm{z}$ from 1695 to $1804 \mathrm{Da}$, assigned to the ionic associates between two cage species and one alkali metal cation $\left[2 \mathrm{M}+\mathrm{Cat}^{+}\right]^{+}$. In the spectra of other iron(II) clathrochelates and bis-clathrochelates studied, the peaks of their ionic associates with alkali metal cations also dominate, whereas the signals of the protonated cage complexes $\left[\mathrm{M}+\mathrm{H}^{+}\right]^{+}$are either not observed or low-intensive.

The ESI-MS spectrum of the hexachloroclathrochelate $\mathrm{Fe}\left(\mathrm{Cl}_{2} \mathrm{Gm}\right)_{3}\left(\mathrm{Bn}-\mathrm{C}_{4} \mathrm{H}_{9}\right)_{2}$, recorded in positive mode, contains no peaks of the cationic species, resulted either from compound oxidation or its association with alkali metal cations. In the negative mode, the intensive peak $[\mathrm{M}]^{-}$of the anion-radical macrobicyclic product of clathrochelate oneelectron reduction was observed.

The spectral data of the cage complexes $\mathrm{FeBd}_{2}\left(\left(\left(\mathrm{CH}_{3}\right)_{2} \mathrm{~N}\right)\left(\mathrm{NH}_{2}\right) \mathrm{Gm}\right)(\mathrm{BF})_{2}, \quad \mathrm{FeBd}_{2}\left(\mathrm{Cl}_{2} \mathrm{Gm}\right)(\mathrm{BF})_{2}$, $\mathrm{FeBd}_{2}\left(\mathrm{Br}_{2} \mathrm{Gm}\right)(\mathrm{BF})_{2}$ and $\mathrm{FeBd}_{2}\left(\mathrm{I}_{2} \mathrm{Gm}\right)(\mathrm{BF})_{2}$ clearly showed the selectivity of their binding with alkali metal cations: the intensities of the corresponding peaks decrease in the series $\mathrm{Cs}^{+}>\mathrm{Na}^{+}>\mathrm{Rb}^{+}>\mathrm{K}^{+}$(Figure 2). It should be noted that for all the iron(II) dihalogenoclathrochelates studied, the most intensive peaks correspond to their ionic associates with $\mathrm{Cs}^{+}$and $\mathrm{Na}^{+}$; no linear relation of their intensities $v s$ the ionic radius of an alkali metal cation is observed. The parent ESI-MS for the iron(II) bis-clathrochelates contain no peaks of their protonated $\left[\mathrm{M}+\mathrm{H}^{+}\right]^{+}$or cation-radical oxidized $[\mathrm{M}]^{+\bullet}$ forms; these, however, may be too weak to be observed.

Note that in the case of a mixture of equimolar amounts of alkali metal ions, for all these complexes the peaks of their ionic associates with $\mathrm{Cs}^{+}$ion are the most intensive (Figures 2 and 3). Another peculiarity of the spectra of the 


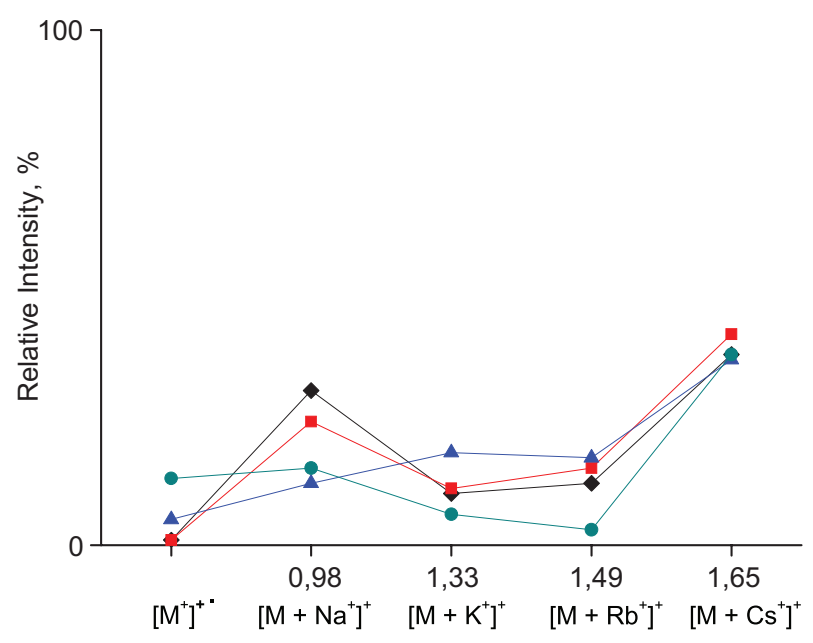

Ionic radius of alkali metal ion, $\AA$

Figure 2. Plots of the relative intensities of the peaks assigned to the $\left[\mathrm{M}+\mathrm{Cat}^{+}\right]^{+}$cations $v s$ the type of an alkali metal cation for for macrobicyclic compounds $\mathrm{FeBd}_{2}\left(\mathrm{Cl}_{2} \mathrm{Gm}\right)(\mathrm{BF})_{2}$ $(\diamond), \mathrm{FeBd}_{2}\left(\mathrm{Br}_{2} \mathrm{Gm}\right)(\mathrm{BF})_{2}(\boldsymbol{\square}), \mathrm{FeBd}_{2}\left(\mathrm{I}_{2} \mathrm{Gm}\right)(\mathrm{BF})_{2}(\boldsymbol{\Delta})$ and $\mathrm{FeBd}_{2}\left(\left(\left(\mathrm{CH}_{3}\right)_{2} \mathrm{~N}\right)\left(\mathrm{NH}_{2}\right) \mathrm{Gm}\right)(\mathrm{BF})_{2}(\bullet)$; the data for the molecular ion $[\mathrm{M}]^{+} \cdot$ are also included.

iron(II) complexes studied is the presence of $\left[\mathrm{M}+\mathrm{Cat}^{+}\right]^{+}$ and $\left[2 \mathrm{M}+\mathrm{Cat}^{+}\right]^{+}$peaks of the ionic associates with clathrochelates-to-alkali metal cation stoichiometric ratios of $1: 1$ and $2: 1$, whereas those of their bis-clathrochelate analogs contain intensive peaks of $1: 1$ associates only.

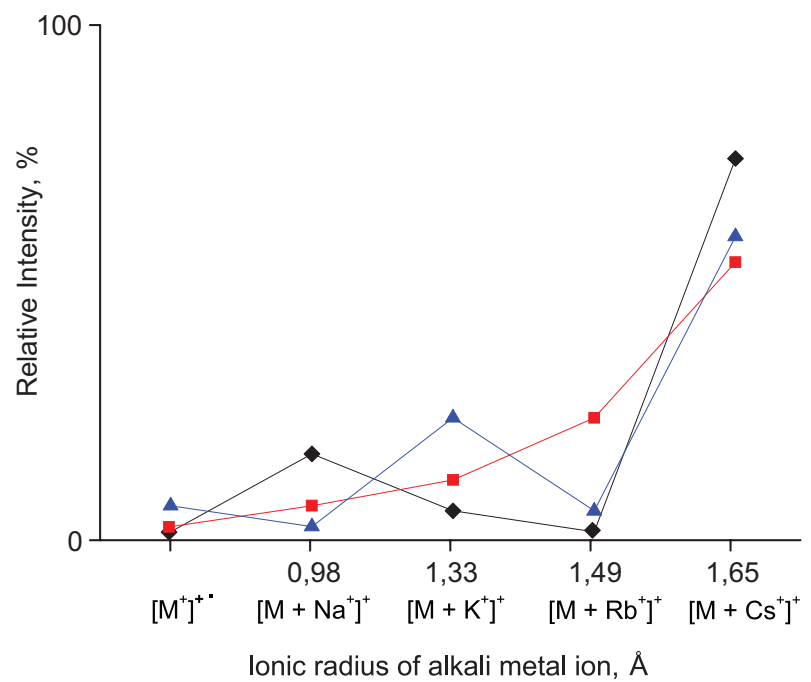

Figure 3. Plots of the relative intensities of the peaks assigned to the $\left[\mathrm{M}+\mathrm{Cat}^{+}\right]^{+}$cations $v s$ the type of an alkali metal cation for the bis-clathrochelates $\left\{\mathrm{FeBd}_{2}(\mathrm{IGm})(\mathrm{BF})_{2}\right\}_{2}(\diamond),\left\{\mathrm{FeBd}_{2}(\mathrm{BrGm})\right.$ $\left.(\mathrm{BF})_{2}\right\}_{2}(\square)$ and $\left\{\mathrm{FeBd}_{2}\left(\left(\mathrm{HOOCC}_{6} \mathrm{H}_{4} \mathrm{~S}\right) \mathrm{Gm}\right)(\mathrm{BF})_{2}\right\}_{2}(\mathbf{\Delta})$; the data for the molecular ion $[\mathrm{M}]^{+} \cdot$ are also included.

The observed dependence of a selectivity of the binding of these alkali metal cations in their equimolar mixture by the iron(II) mono- and bis-clathrochelates on the nature of their ribbed substituents is the result of fine effects of cation recognition by these cage complexes.

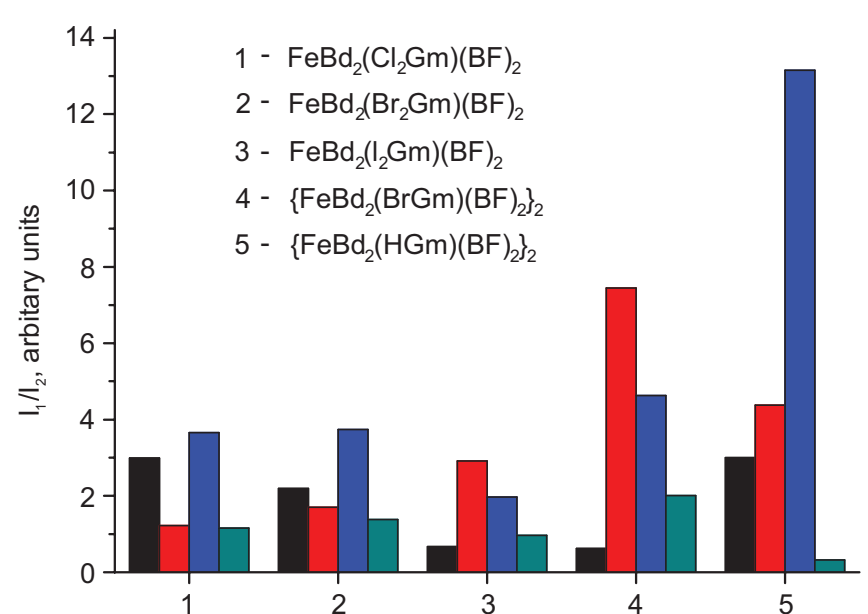

Figure 4. Relative intensities of the peaks assigned to the ionic associates $\left[\mathrm{M}+\mathrm{Cat}^{+}\right]^{+}$for the iron(II) mono- and bisclathrochelates and the pairs of alkali metal cations $\mathrm{Na}^{+} / \mathrm{K}^{+}(\boldsymbol{\square})$; $\mathrm{Cs}^{+} / \mathrm{Na}^{+}(\square) ; \mathrm{Cs}^{+} / \mathrm{K}^{+}(\square)$ and $\mathrm{Rb}^{+} / \mathrm{K}^{+}(\mathbf{\square})$.

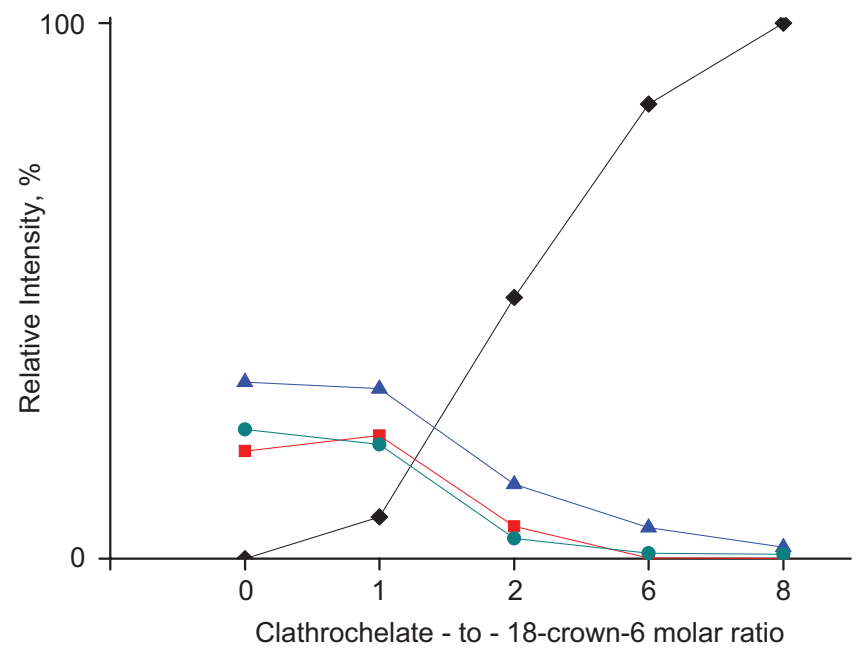

Figure 5. Plots of the intensities of the peaks of different ionic associates $\left\{\left[\mathrm{M}+\mathrm{Cs}^{+}\right]^{+}(\boldsymbol{\square}),\left[\mathrm{M}+\mathrm{Cs}^{+}+\mathrm{CH}_{3} \mathrm{OH}\right]^{+}(\boldsymbol{\Delta})\right.$ and $\left.\left[2 \mathrm{M}+\mathrm{Cs}^{+}\right]^{+}(\bullet)\right\}$ of $\mathrm{Cs}^{+}$cation with the clathrochelate $\mathrm{FeBd}_{2}\left(\mathrm{Br}_{2} \mathrm{Gm}\right)(\mathrm{BF})_{2}$ and with 18-crown-6 $(\diamond)$ as a concurrent ligand $v_{s}$ the clathrochelate-to-18-crown-6 molar ratio.

A stepwise addition of 18-crown-6 as a competitive ligand to the acetonitrile solution of the clathrochelate $\mathrm{FeBd}_{2}\left(\mathrm{Br}_{2} \mathrm{Gm}\right)(\mathrm{BF})_{2}$ with the equimolar amount of cesium tetraphenylborate caused the substantial changes in the intensities of the peaks in its ESI-MS: the intensity of the peak with $m / z 397 \mathrm{Da}$ assigned to the cationic species [18crown- $\left.6+\mathrm{Cs}^{+}\right]^{+}$increases, whereas for those assigned to the ionic associates of this clathrochelate with $\mathrm{Cs}^{+}$cation correspondingly decreases. New peaks of either the molecular clathrochelate ions or their fragments do no appear in the spectrum. Therefore, 18-crown-6 as a competitive ligand playes a role of the so-called "anticationization agent" by suppressing the main pathway of the ionization of the cage complexes, i.e. the formation of their ionic associates with alkali metal cations. 


\section{Conclusions}

We have studied the peculiarities of the ionization of different iron(II) mono- and bis-clathrochelates under the conditions of ESI-MS experiments. The macrobicyclic iron(II) oximehydrazonate as an ionic associate of the macrobicyclic cation with $\mathrm{BF}_{4}^{-}$anion undergoes the ionization by its heterolytic dissociation. The main pathways of ionization of the dioximate cage and biscage intracomplexes are substantially affected by ribbed substituents in their chelate fragments. The alkyl- and amine-containing macrobicyclic complexes easily form anion-radical species $[\mathrm{M}]^{-*}$ by one-electron oxidation of their polyazomethine cage frameworks, whereas in the case of iron(II) dihalogenoclathrochelates the most intensive peaks belong to their ionic associates with monocharged alkali metal cations. Positive-mode ESI-MS spectrum of the iron(II) hexachloroclathrochelate have not shown detectable peaks of the cationic species, resulted either from its oxidation to the corresponding cation-radical or from the formation of ionic associates with alkali metal cations. An intensive peak observed in the negative mode was assigned to the anion-radical product $[\mathrm{M}]^{-\bullet}$ of clatrochelate one-electron reduction. The iron(II) monoclathrochelates form two types of ionic associates with alkali metal cations with both the 1:1 and 2:1 stoichiometries. The ESI-MS of the bis-cage complexes contains intensive peaks of only 1:1 ionic associates with high affinity towards $\mathrm{Cs}^{+}$cation.

Acknowledgements. This research was supported by the European Community's Seventh Framework Programme (FP7/2007-2013, grant agreement 295160), RFBR (grants 12-03-00955, 13-03-90452 and 13-03-90459) and RAS (programs 6 and P8).

\section{References}

1. Voloshin Y.Z., Kostromina N.A., Krämer R. Clathrochelates: Synthesis, Structure and Properties, Elsevier, Amsterdam, 2002.

2. Voloshin Y., Varzatskii O., Shul'ga S., Novikov V., Belov A., Makarenko I., Dubey I., Krivorotenko D., Negrutska V., Zhizhin K., Kuznetsov N., Bubnov Y. Proc. 10th EUROBIC, Thessaloniki, Greece, 22-26 June, 2010, p. 29-38.

3. Novikov V.V., Varzatskii O.A., Negrutska V.V., Bubnov Y.N., Palchykovska L.G., Dubey I.Y., Voloshin Y.Z. J. Inorg. Biochem. 2013, 124, 42-45.

4. Varzatskii O.A., Novikov V.V., Shulga S.V., Belov A.S., Vologzhanina A.V., Negrutska V.V., Dubey I.Y., Bubnov Y.N., Voloshin Y.Z. Chem. Commun. 2014, 50, 3166-3168.

5. Losytskyy M.Y., Kovalska V.B., Varzatskii O.A., Sergeev A.M., Yarmoluk S.M., Voloshin Y.Z. J. Fluoresc. 2013, 23, 889-895.

6. Kovalska V.B., Losytskyy M.Yu., Varzatskii O.A., Cherepanov V.V., Voloshin Y.Z., Mokhir A.A., Yarmoluk S.M., Volkov S.V. J. Bioorg. Med. Chem. 2014, 1883-1888.

7. Smith S.V., Harrowfield J.M., Di Bartolo N.M., Sargeson A.M., PCT Int. Appl. WO 00 40, 585 (Cl. C07D487/08) Publ. 13.07.2000

8. Donnelly P.S., Harrowfield J.M., Skelton B.W., White A.H. Inorg. Chem. 2000, 39, 5817-5830.

9. Donnelly P.S., Harrowfield J.M. J. Chem. Soc., Dalton Trans. 2002, 906-913.
10. Smith S.V. J. Inorg. Biochem. 2004, 98, 1874-1901.

11. Di Bartolo N., Sargeson A.M., Smith S.V. Org. Biomol. Chem. 2006, 4, 3350-3357.

12. Voss S.D., Smith S.V., Di Bartolo N., McIntosh L.J., Cyr E.M., Bonab A.A., Carter E.A., Fischman A.J., Treves S.T., Gillies S.D., Sargeson A.M., Huston J.S., Packard A.B. Proc. Natl. Acad. Sci. USA 2007, 104, 17489-17493.

13. Cai H., Fissekis J., Conti P.S. Dalton Trans. 2009, 5395-5400.

14. Ma M.T., Karas J.A., White J.M., Scanlon D., Donnelly P.S. Chem. Commun. 2009, 3237-3239.

15. Cai H., Li Z., Huang C.-W., Park R., Shahinian A.H., Conti P.S. Nucl. Med. Biol. 2010, 37, 57-65.

16. Dittrich B., Harrowfield J.M., Koutsantonis G.A., Nealon G.L. Dalton Trans. 2010, 39, 3433-3448.

17. Liu S., Li Z., Yap L.-P., Huang C.-W., Park R., Conti P.S. Chem. Eur. J. 2011, 17, 10222-10225.

18. Ma M.T., Neels O.C., Denoyer D., Roselt P., Karas J.A., Scanlon D.B., White J.M., Hicks R.J., Donnelly P.S. Bioconjugate Chem. 2011, 22, 2093-2103.

19. Ma M.T., Cooper M.S., Paul R.L., Shaw K.P., Karas J.A., Scanlon D., White J.M., Blower P.J., Donnelly P.S. Inorg. Chem. 2011, 50, 6701-6710.

20. Chen K., Wang X., Lin W.-Y., Shen C. K.-F., Yap L.-P., Hughes L.D., Conti P.S. ACS Med. Chem. Lett. 2012, 3, 1019-1023.

21. Qin C.-J., James L., Chartres J.D., Alcock L.J., Davis K.J., Willis A.C., Sargeson A.M., Bernhardt P.V., Ralph S.F. Inorg. Chem. 2011, 50, 9131-9140.

22. Bernhardt P.V., Font H., Gallego C., Martínez M., Rodríguez C. Inorg. Chem. 2012, 51, 12372.

23. Voloshin Y.Z., Varzatskii O.A., Bubnov Y.N. Russ. Chem. Bull. 2007, 56, 577-605.

24. Voloshin Y.Z., Varzatskii O.A., Zhizhin K.Y., Kuznetsov N.T., Bubnov Y.N. Russ. Chem. Bull. 2006, 55, 22-25.

25. Voloshin Y.Z., Erdyakov S.Y., Makarenko I.G., Lebed E.G., Potapova T.V., Svidlov S.V., Starikova Z.A., Pol'shin E.V., Gurskii M.E., Bubnov Y.N. Rus. Chem. Bull. 2007, 56, 17871794.

26. Erdyakov S.Y., Voloshin Y.Z., Makarenko I.G., Lebed E.G., Potapova T.V., Ignatenko A.V., Vologzhanina A.V., Gurskii M.E., Bubnov Y.N. Inorg. Chem. Commun. 2009, 12, 135-139.

27. Kuznetsov N.T., Belaya I.G., Dolganov A.V., Zelinsky G.E., Matveev E.Y., Zhizhin K.Y., Voloshin Y.Z., Bubnov Y.N. Russ. Chem. Bull. 2011, 60, 2518-2521.

28. Svidlov S.V., Varzatskii O.A., Potapova T.V., Vologzhanina A.V., Bukalov S.S., Leites L.A., Voloshin Y.Z., Bubnov Y.N. Inorg. Chem. Commun. 2014, 43, 142-145.

29. Voloshin Y.Z., Varzatskii O.A., Kochubey D.I., Vorontsov I.I., Bubnov Y.N. Inorg. Chim. Acta 2009, 362, 149-158.

30. Vershinin M.A., Burdukov A.B., Boguslavskii E.G., Pervukhina N.V., Kuratieva N.V., Eltsov I.V., Reznikov V.A., Varzatskii O.A., Voloshin Y.Z., Bubnov Y.N. Inorg. Chim. Acta 2011, 366, 91-97.

31. Belov A.S., Prikhod'ko A.I., Novikov V.V., Vologzhanina A.V., Bubnov Y.N., Voloshin Y.Z. Eur. J. Inorg. Chem. 2012, 45074514.

32. Voloshin Y.Z., Zavodnik V.E., Varzatskii O.A., Belsky V.K., Palchik A.V., Strizhakova N.G., Vorontsov I.I., Antipin M.Y. Dalton Trans. 2002, 1193-1202.

33. Voloshin Y.Z., Varzatskii O.A., Belov A.S., Starikova Z.A., Suponitsky K.Y., Novikov V.V., Bubnov Y.N. Inorg. Chem. 2008, 47, 2155-2167.

34. Varzatskii O.A., Voloshin Y.Z., Korobko S.V., Shulga S.V., Krämer R., Belov A.S., Vologzhanina A.V., Bubnov Y.N. Polyhedron 2009, 28, 3431-3438, and references cited therein.

35. Voloshin Y.Z., Varzatskii O.A., Belov A.S., Starikova Z.A., Dolganov A.V., Novikov V.V., Bubnov Y.N. Inorg. Chim. Acta 2011, 370, 322-332. 
ESI-MS Study of Iron(II) Mono- and Bis-Clathrochelates

36. Voloshin Y.Z, Belaya I.G., Belov A.S., Platonov V.E., Maksimov A.M., Vologzhanina A.V., Starikova Z.A., Dolganov A.V., Novikov V.V., Bubnov Y.N. Dalton Trans. 2012, 41, 737 -746, and references cited therein.

37. Belaya I.G., Zelinskii G.E., Belov A.S., Varzatskii O.A., Novikov V.V., Dolganov A.V., Kozlowski H., Szyrwiel Ł., Bubnov Y.N., Voloshin Y.Z. Polyhedron 2012, 40, 32-39.

38. Voloshin Y.Z., Varzatskii O.A., Palchik A.V., Polshin E.V., Maletin Y.A., Strizhakova N.G., Polyhedron 1998, 17, 43154326.
39. Voloshin Y.Z., Stash A.I., Varzatskii O.A., Belsky V.K., Maletin Y.A., Strizhakov N.G., Inorg. Chim. Acta 1999, 284, 180-190.

40. Voloshin Y.Z., Varzatskii O.A., Kron T.E., Belsky V.K., Zavodnik V.E., Palchik A.V. Inorg. Chem. 2000, 39, 1907 1918.

41. Burdukov A.B., Vershinin M.A., Pervukhina N.V., Voloshin Y.Z., Varzatskii O.A. Russ. Chem. Bull. 2006, 55, 1982-1988.

42. Voloshin Y.Z., Belov A.S., Varzatskii O.A., Shul'ga S.V., Stuzhin P.A., Starikova Z.A., Lebed E.G., Bubnov Y.N. Dalton Trans. 2012, 41, 921-928. 